\title{
Novel, Highly Soluble Non-Peripherally Phthalocyanines Bearing Bulky Groups Containing Fluorine Atoms: Synthesis, Characterization, Spectral and Improved Photophysicochemical Properties
}

\author{
Yeni Flor Zincirli Çözünür Ftalosiyaninler: Sentezi, \\ Karakterizasyonu, Fotokimyasal ve Fotofiziksel Özellikleri
}

\author{
Research Article
}

Göknur Yaşa Atmaca and Ali Erdoğmuş*

Department of Chemistry, Yıldız Technical University, Esenler, Istanbul, Turkey.

\section{A B S TR AC T}

\begin{abstract}
The synthesis of a new phthalonitrile (1) was described by treating 3-nitrophthalonitrile with 4-(3,3,4,4,5,5,6,6,7,7,8,8,9,9,10,10,10-heptadecafluorodecylthio)phenol. After that, its soluble zinc(II)(2), magnesium(II) (3), cobalt(II) (4) and indium chloride(III) (5) non-peripheral phthalocyanine derivatives were reported for the first time. The newly synthesized metallo phthalocyanine derivatives were characterized by mass spectrometry, UV-Vis, FT-IR, and ${ }^{1} \mathrm{H}-\mathrm{NMR}$ spectroscopy. Photochemical and photophysical (photodegradation, singlet oxygen and fluorescence quantum yields) properties of the phthalocyanines were carried out in tetrahydrofuran (THF). Metallo-phthalocyanines, which containing a bulky long alkyl chain bearing fluorine atoms, have high solubility in known organic solvents such as THF, dichloromethane (DCM), chloroform $\left(\mathrm{CHCl}_{3}\right)$ and toluene and do not show aggregation. Besides, the effect of metal ion types in phthalocyanines core ( 2 , 3, 4 and 5) were also investigated. The effects of the substitution with fluoroalkynyl-functionalized groups on these parameters mentioned were also compared along with the previously synthesized peripherally tetra and octa substituted phthalocyanines. Non peripherally position of the substituents on Pc improved photophysical and photochemical properties.
\end{abstract}

\section{Key Words}

Phthalocyanines, photophysic, photochemistry.

\section{öz}

$\mathbf{Q}$ u çalışmada yeni 3,3,4,4,5,5,6,6,7,7,8,8,9,9,10 3-nitroftalonitril ve onun çözünebilir non-peripheral çinko B (II) (2), magnezyum (II) (3), kobalt (II) (4) ve indiyum klorür (III) (5) ftalosiyanin türevlerinin sentezi ilk kez rapor edildi. Yeni sentezlenmiş metalo ftalosiyanin türevlerinin yapıları, kütle, UV-Vis, FT-IR, ve ${ }^{1} H-N M R$ spektroskopisi kullanılarak karakterize edildi. Fotokimyasal (Singlet Oksijen foto bozunma kuantum verimleri) ve fotofiziksel (floresans kuantum verimleri) özellikleri tetrahidrofuran (THF) içinde incelendi. Flor atomları taşıyan uzun alkil zincirli gruplar taşıyan metallo fitalosiyaninlerin (2-5), THF, diklorometan (DCM), kloroform $\left(\mathrm{CHCl}_{3}\right)$ ve toluen gibi bilinen organik çözücülerde yığılma göstermeden yüksek çözünürlüğe sahip oldukları görüldü. Bunun yanı sıra, merkez metal iyon türü ve substitüentin pozisyon etkisi daha önceki çalışmalarla karşılaştırılarak çalışıldı. Non peripheral konumun fotofiziksel ve fotokimyasal özellikleri geliştirdiği gözlendi.

\section{Anahtar Kelimeler}

Ftalosiyaninler, fotofizik, fotokimya.

Article History: Received: Apr 1, 2016; Revised: Aug 2, 2016; Accepted: Nov 21, 2016; Available Online: Apr 1, 2017.

DOI: 10.15671/HJBC.2017.137

Correspondence to: A. Erdoğmuş, Department of Chemistry, Yıldız Technical University, Esenler, İstanbul, Turkey. 


\section{INTRODUCTION}

$\mathrm{M}$ etallophthalocyanines

(MPcs) have captivated concern due to their divers application areas in energy transfer, laser technology, electrophotography, chemical sensors, optical data collection, liquid crystal, one-dimensional metals and pigments and photodynamic therapy (PDT) [1,2]. PDT is a therapy of cancer in which special light is used to activate a ligh absorbing molecule (photosensitizer) for generation of cytotoxic singlet oxygen [3]. One of the most important property of this therapy is that it involves the selective uptake of a sensitizer by the cells and causes selective destruction when activated [4]. Over the past two decades, the use of phthalocyanines as drugdelivery agents for PDT has gained increasing momentum because of their long-wavelength absorptions with high extinction coefficients, red fluorescence emission and high singlet oxygen quantum yields [5]. But, the main problem on their application areas is solubility $[5,6]$. Unsubstituted phthalocyanines (Pcs) are generally insoluble in a solvent [7]. They can become soluble by attaching appropriate substituents such as hydrophilic groups [8,9]. Moreover,this properties can be changed by depending on the substituents at peripheral or non-peripheral positions on phthalocyanine ring [10]. In this way, the novel complexes, which contains long alkyl chain containing fluor atoms, are successful combined with their positions (peripherally and non-peripherally) and substituents. Because, the fluoro-functionalized phthalocyanines were seen with their good solubility. The increased solubility may be due to fluorine which has the highest electronegativity of all elements [11]. In addition to appropriate substituent, nonperipheral positions of the phthalocyanines improved photophysical properties [12] Besides, fluorinated phthalocyanines enhanced photosensitizer efficiency for PDT when compared to non-fluorinated ones [11]. In this work, the syntheses, characterizations, agreggation and photophysicochemicsal properties of four novel metallophthalocyanines (2 to 5) non-peripherally substituted with four long chain fluoro groups were reported. The effects of substituent position on the Pc scketal with improved fluorescence, singlet oxygen and photodegradation quantum yields mentioned were also compared with the previously reported fluoro group-containing phthalocyanines counterparts. The type of central metal cations in the phthalocyanine cavity on these properties were also determined. Newly synthesized complexes showed in Scheme 1.

\section{Experimental}

\section{Materials and Equipment}

All chemicals and solvents used were analytical grade and commercially purchased and were used as received without further purification. Column chromatography was performed on silica gel 60 (0.04-0.063 mm). FT-IR spectra ( $\mathrm{KBr}$ pellets) were measured with a Perkin Elmer Spectrum One Spectrometer. Absorption spectra in the UV-Visible region were obtained with a Shimadzu 2001 UV spectrophotometer. Elemental analyses were recorded with a Thermo Flash EA 1112 Series. Fluorescence spectra were measured using a Varian Eclipse spectrofluorometer using $1 \mathrm{~cm}$ path length cuvettes at room temperature. ${ }^{1} \mathrm{H}$ NMR spectra were recorded in deutareted chloroform $\left(\mathrm{CDCl}_{3}\right)$ solutions on a Varian $500 \mathrm{MHz}$ spectrometer. Photo-irradiations were measured using a General Electric quartz line lamp (300W). A $600 \mathrm{~nm}$ glass cut off filter (Schott) and a water filter were used to filter off ultraviolet and infrared radiations respectively. An interference filter (Intor, $700 \mathrm{~nm}$ with a band width of $40 \mathrm{~nm}$ ) was additionally placed in the light path before the sample. Light intensities were measured with a POWER MAX 5100 (Mol electron detector in corporated) power meter. The mass spectra were acquired on a Bruker Daltonics (Bremen, Germany) Micro TOF mass spectrometer equipped with an electron spray ionization (ESI) source. The instrument was operated in positive ion mode using am/z range of 50-3000. The capillary voltage of the ion source was set at $6000 \mathrm{~V}$ and the capillary exit at $190 \mathrm{~V}$. The nebulizer gas flow was 1 bar and drying gas flow $8 \mathrm{~mL} / \mathrm{min}$ (MALDI $\mathrm{MS})$.

\section{Physical and Photochemical Studies}

\section{Fluorescence Quantum Yields}

Fluorescence quantum yields $\left(\Phi_{\mathrm{F}}\right)$ were determined by comparative method [13] Equation (1): 

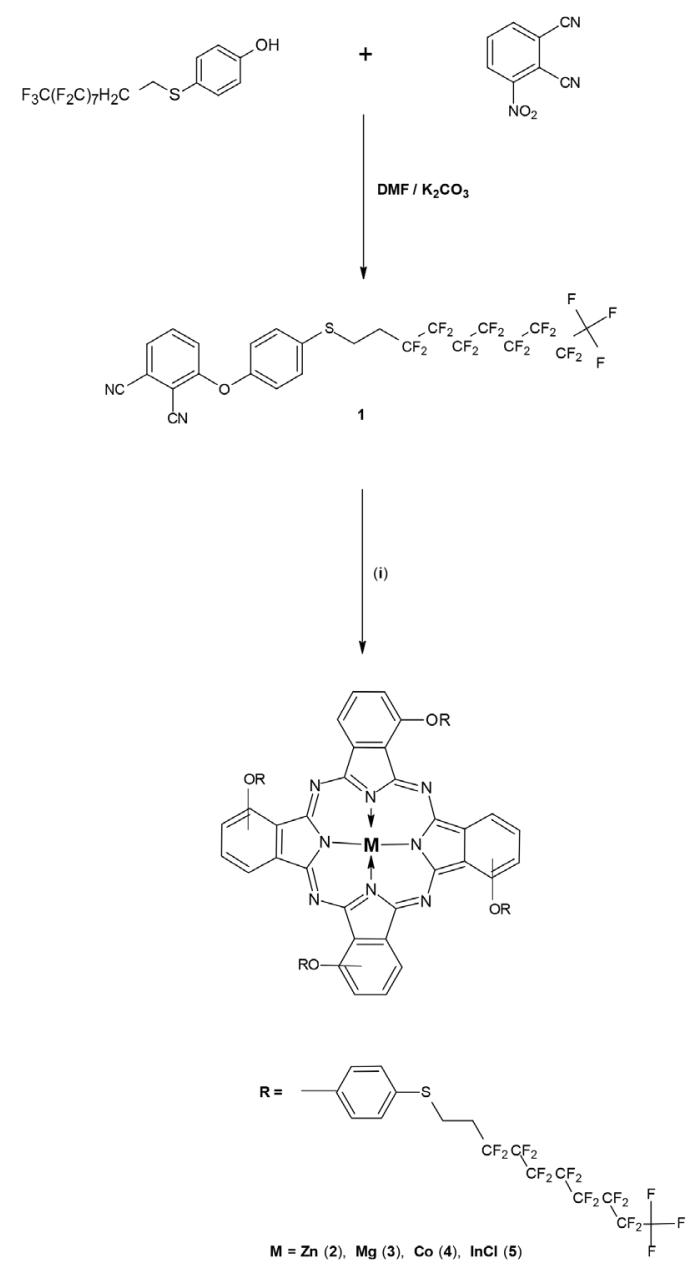

Scheme 1. Synthesis of the starting compound and metallo phthalocyanines: (i) anhydrous $\mathrm{Zn}(\mathrm{OAC})_{2}, \mathrm{Mg}(\mathrm{OAC})_{2}, \mathrm{CoCl}{ }_{2}$ or $\mathrm{InCl}_{3}$ 1-pentanol, argon atm.

$\Phi_{F}=\Phi_{F(S t d)} \cdot\left[\left(F \cdot A_{S t d} \cdot n^{2}\right) /\left(F_{S t d} \cdot A \cdot n^{2}\right)\right]$

where $F$ and $F_{\text {std }}$ are the areas under the fluorescence curves of the MPc derivatives and the reference, respectively. $A$ and $A_{\text {std }}$ are the absorbances of the sample and reference at the excitation wavelength, and $\mathrm{n}^{2}$ and $\mathrm{n}^{2}$ std are the refractive indexes of solvents used for the sample and standard, respectively [14]. Unsubstituted $\mathrm{ZnPc}$ was used as a standard; $\Phi_{\mathrm{F}}=0.23$ [14] in THF. All of the samples and the standard were excited at the same relevant wavelength.

\section{Singlet Oxygen Quantum Yields}

Quantum yields of singlet oxygen photogeneration were determined in air (no oxygen bubbled) using the relative method with unsubstituted $\mathrm{ZnPc}$ as reference and diphenyl isobenzofuran (DPBF) as chemical quencher $[3,15]$ Equation (2):

$\Phi_{\Delta}=\Phi_{\Delta(\text { Std })}\left[\left(R \cdot l_{\text {abs (std) }}\right)\right] / R_{\text {std }} \cdot l_{\text {abs }}$

where $\Phi_{\text {Std } \Delta}$ is the singlet oxygen quantum yield for the unsubstituted ZnPc standard; $\Phi^{\text {std }}=0.53$ [14] in THF. $R$ and $R_{\text {Std }}$ are the DPBF photo bleaching rates in the presence of the respective sample and standard, respectively. $I_{\text {abs }}$ and $I_{\text {stdabs }}$ are the rates of light absorption by the sample and standard, respectively. The concentration of quencher (DPBF) was lowered to $\sim 3 \times 10^{-5} \mathrm{~mol} \mathrm{dm}^{-3}$ to avoid chain reactions induced by DPBF in the presence of singlet oxygen [13]. Solutions, that contain DPBF, were prepared in the dark and irradiated in the $Q$ band region $[13,16]$. The degradation of DPBF at $417 \mathrm{~nm}$ was monitored after each $5 \mathrm{~s}$ irradiation. The light intensity of $7.05 \times 10^{15}$ photons $\left(\mathrm{s}^{-1} \mathrm{~cm}^{-2}\right)$ was used for determinations. 


\section{Edation Quantum Yields}

Photodegradation quantum yield $\left(\Phi_{d}\right)$ determinations were carried out using the experimental set-up described in literature $[15,17]$ Equation (3):

$\Phi_{d}=\left[\left(C_{0}-C_{t}\right) \cdot V \cdot N_{A}\right] /\left[I_{a b s} \cdot S \cdot t\right]$

where $C_{0}$ and $C_{t}$ are the sample concentrations before and after irradiation respectively, $\mathrm{V}$ is the reaction volume, $\mathrm{N}_{\mathrm{A}}$ is the Avogadro's constant, $\mathrm{S}$ is the irradiated cell area, $t$ is the irradiation time, labs is the overlap integral of the radiation source light intensity and the absorption of the sample. A light intensity of $2.42 \times 10^{16}$ photons $\mathrm{s}^{-1} . \mathrm{cm}^{-2}$ was employed for $\Phi_{d}$ determinations $[3,17]$.

\section{Synthesis}

4-[(3,3,4,4,5,5,6,6,7,7,8,8,9,9,10,10, 10 -Heptadecafluoro-Decylthio) Phenoxy]Phthalonitrile (1)

The 3-nitrophthalonitrile $(0.5 \mathrm{~g} 2.92 \mathrm{mmol})$ was dissolved in $15 \mathrm{~mL}$ dry DMF under inert argon atmosphere and 4- $(3,3,4,4,5,5,6,6,7,7,8,8,9,9$, $10,10,10$ - heptadecafluorodecylthio)phenol (1.7 g $2.92 \mathrm{mmol}$ ) was added at room temperature. After stirring for $30 \mathrm{~min}$ at room temperature, finely ground anhydrous potassium carbonate $(1.2 \mathrm{~g} 8.76 \mathrm{mmol})$ was added in portions for 2 $\mathrm{h}$ and the reaction mixture was stirred at room temperature for $24 \mathrm{~h}$. Then, the mixture was poured into $200 \mathrm{~mL}$ ice-water and the precipitate was filtered off, washed with water and methanol and then dried. The crude product was purified by chromatography over a silica gel column using a mixture of $\mathrm{CHCl}_{3}: \mathrm{MeOH}(20: 1 \mathrm{v}: \mathrm{v})$, Yield: $1.1 \mathrm{~g}$ (54.5\%). IR spectrum ( $\left.\mathrm{cm}^{-1}\right): 3075(\mathrm{Ar}-\mathrm{CH}), 2235$ $(C \equiv N), 1604(C=C), 1579,1482,1376(C-F), 1316$, 1256, 1079 (C-O-C), 671 (C-S-C). ${ }^{1} \mathrm{H}$ NMR $\left(\mathrm{CDCl}_{3}\right): \delta$ $=7.88-7.54(\mathrm{~m}, 3 \mathrm{H}, \mathrm{Ar}-\mathrm{H}), 7.41-7.16(\mathrm{~m}, 4 \mathrm{H}, \mathrm{Ar}-\mathrm{H})$, $3.20\left(\mathrm{t}, 2 \mathrm{H}, \mathrm{CH}_{2}\right), 2.64-2.48\left(\mathrm{~m}, 2 \mathrm{H}, \mathrm{CH}_{2}\right)$. MS (ESIMS) m/z: Calc.698; Found: $721\left[\mathrm{M}^{+} \mathrm{Na}^{+}\right.$.

General Procedure for the Syntheses of (4) Tetra $[(3,3,4,4,5,5,6,6,7,7,8,8,9,9,10,10,10$ Heptadecafluorodecylthio)phenoxy]Phthalocyaninato Zn(II) (2), Mg(II) (3), Co(II) (4) and $\ln (\mathrm{III}) \mathrm{Cl}$ (5)

Compound $1(0.30 \mathrm{~g}, 0.43 \mathrm{mmol})$, anhydrous metal salts $(0.43 \mathrm{mmol} ; 0.094 \mathrm{~g} \mathrm{Zn(OAc)})_{2} 0.041 \mathrm{~g}$
$\mathrm{Mg}(\mathrm{OAC})_{2}, 0.053 \mathrm{~g} \mathrm{CoCl}_{2}$ and $0.095 \mathrm{~g} \mathrm{InCl}_{3}$ ) and 3 $\mathrm{mL}$ dry pentanol were placed in a standard Schlenk tube in the presence of 1,8-diazabicyclo[5.4.0] undec-7-ene (DBU) $(0.31 \mathrm{~mL}, 0.20 \mathrm{mmol})$ under argon gase and held at reflux temperature for 10 h. After cooling to room temperature, the reaction mixtures were precipitated by adding it drop-wise into water. The green precipitation was collected by filtration and washed with water, methanol, ethanol and hexane and then dried. The crude metallophthalocyanine derivatives were purified by chromatography over a silica gel column using $\mathrm{CHCl}_{3}$ and a mixture of $\mathrm{CH}_{2} \mathrm{Cl}_{2}$ and THF $(5: 50 \mathrm{v} / \mathrm{v})$. (2): Yield: $155 \mathrm{mg}$ (12.6\%). UV-Vis (THF): $\max$ $\mathrm{nm}(\log \varepsilon) 340$ (3.57), 622 (3.46), 692 (4.24). IR spectrum $\left(\mathrm{cm}^{-1}\right): 3072(\mathrm{Ar}-\mathrm{CH}), 2927,2850(\mathrm{CH})$, $1578(\mathrm{C}=\mathrm{C}), 1483,1333(\mathrm{C}-\mathrm{F}), 1234,1087(\mathrm{C}-\mathrm{O}-\mathrm{C})$, 957, 803, 743, 705, 658 (C-S-C). ${ }^{1} \mathrm{H}$ NMR $\left(\mathrm{CDCl}_{3}\right)$ : $\delta=7.8-7.1(28 \mathrm{H}, \mathrm{m}, \mathrm{Ar}-\mathrm{H}), 3.7-3.1\left(\mathrm{~m}, 8 \mathrm{H}, \mathrm{CH}_{2}\right), 2.5-$ $2.0\left(\mathrm{~m}, 8 \mathrm{H}, \mathrm{CH}_{2}\right)$. MS (ES+), (m/z): Calc. 2858.98; Found: $2859.05\left[^{\mathrm{M}^{+}}\right.$. (3): Yield: $134 \mathrm{mg}(11.1 \%)$. UV-Vis (THF): $\max \mathrm{nm}(\log \varepsilon) 325$ (3.17), 623 (3.00), 690 (3.92). IR spectrum $\left(\mathrm{cm}^{-1}\right): 3070$ (Ar$\mathrm{CH}), 2959,2848(\mathrm{CH}), 1578(\mathrm{C}=\mathrm{C}), 1481,1444$, 1331 (C-F), 1234, 1119,1144 (C-O-C), 955, 881, 746, 703,659 (C-S-C). ${ }^{1} \mathrm{H}$ NMR $\left(\mathrm{CDCl}_{3}\right): \delta=7.7-6.9(28 \mathrm{H}$, $\mathrm{m}, \operatorname{Ar}-\mathrm{H}), 3.51-2.80\left(\mathrm{~m}, 8 \mathrm{H}, \mathrm{CH}_{2}\right), 2.35-2.00(\mathrm{~m}$, $\left.8 \mathrm{H}, \mathrm{CH}_{2}\right)$. MS (ES+), (m/z): Calc. 2817.88; Found: 2818.36 [M]+. (4): Yield: $115 \mathrm{mg}$ (9.5\%). UV-Vis (THF): $\max n m(\log \varepsilon) 324$ (3.69), 612 (3.27), 675 (3.63). IR spectrum $\left(\mathrm{cm}^{-1}\right): 3058-3016(\mathrm{Ar}-\mathrm{CH})$, $2957(\mathrm{CH}), 1584(\mathrm{C}=\mathrm{C}), 1483,1431,1331$ (C-F), 1232, 1119, 1088 (C-O-C), 955, 822, 747, 705, 658 (C-S-C). ${ }^{1} \mathrm{H} \mathrm{NMR}\left(\mathrm{CDCl}_{3}\right): \delta=7,8-7.12(28 \mathrm{H}, \mathrm{m}, \mathrm{Ar}-\mathrm{H}), 3.30-$ $3.10\left(\mathrm{~m}, 8 \mathrm{H}, \mathrm{CH}_{2}\right), 2.60-2.30\left(\mathrm{~m}, 8 \mathrm{H}, \mathrm{CH}_{2}\right) . \mathrm{MS}(\mathrm{ES}+)$, (m/z): Calc. 2852.50; Found: 2852.65 [M]+. (5): Yield: $122 \mathrm{mg}$ (9.8\%). UV-Vis (THF): $\max \mathrm{nm}$ (log ع) 359 (3.17), 643 (3.24), 713 (3.58). IRspectrum $\left(\mathrm{cm}^{-1}\right): 3075(\mathrm{Ar}-\mathrm{CH}), 2959(\mathrm{CH}), 1579(\mathrm{C}=\mathrm{C}), 1481$, 1331 (C-F), 1234, 1198,1113 (C- O-C), 972, 804, 737, 704,658 (C-S-C). ${ }^{1} \mathrm{H} \mathrm{NMR}\left(\mathrm{CDCl}_{3}\right): \delta=8.2-6.9(28 \mathrm{H}$, $\mathrm{m}, \mathrm{Ar}-\mathrm{H}), 3.45-3.12\left(\mathrm{~m}, 8 \mathrm{H}, \mathrm{CH}_{2}\right), 2.70-2.40(\mathrm{~m}, 8 \mathrm{H}$, $\left.\mathrm{CH}_{2}\right)$. MS (ES+), (m/z): Calc. 2943.85; Found: $2909.40\left[\mathrm{M}-\mathrm{Cl}^{+} \mathrm{H}\right]^{+}$.

\section{RESULTS and DISCUSSION}

\section{Synthesis and Characterization}

The common reaction route to novel phthalocyanines ( 2 to 5 ) is showed in Scheme 1. These new phthalocyanine complexes were 


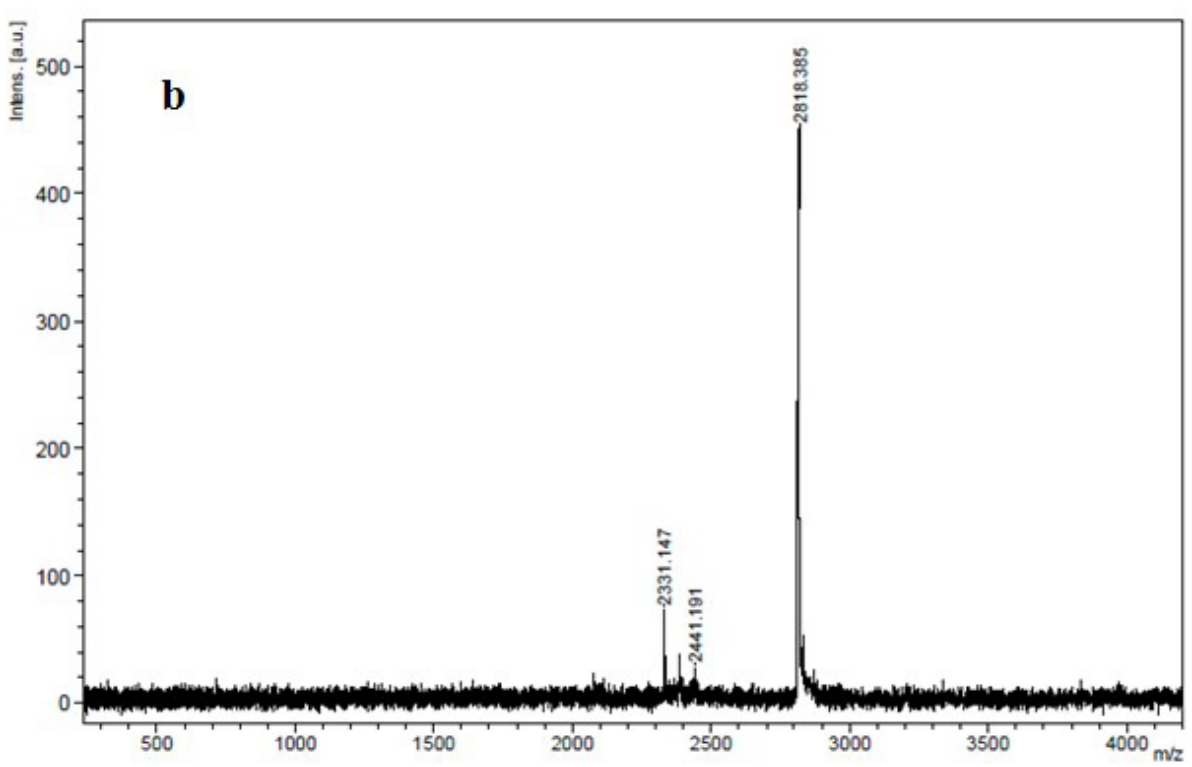

Figure 1. The mass spectra of the compounds 2 (a) and 3 (b).

prepared by the template cyclotetramerization of the phthalonitrile compound (1), and anhydrous metal salts in the presence of 1-pentanol and strong base DBU as a catalyst at reflux temperature under argon gase. All phthalocyanines synthesized were purified by column chromatography. They were obtained in a modarete yield for phthalocyanine compounds $(12.6 \%$ for $2,11.1 \%$ for $3,9.5 \%$ for 4 and $9.8 \%$ for 5 ) and were characterized by the spectral data (UV-Visible, FTIR, ${ }^{1} \mathrm{H}$ NMR and Mass spectroscopies).

In general, unsubtituted phthalocyanine complexes did not have solubility in known organic solvents; but insertion of different substituents on the ring improves the solubility [18]. The new complexes ( 2 to 5 ) have well solubility in organic solvents because of the substituent carring long alkyl chain bearing fluorine atoms.

Spectroscopic data were consistent with expected ones. In IR spectrum of the compounds, the characteristic vibrations corresponding to $\mathrm{CN}$ were observed at $2235 \mathrm{~cm}^{-1}$ for 1 and disappeared for $2,3,4$ and 5 as expected. The $\mathrm{C}-\mathrm{O}-\mathrm{C}$ vibrations were at $1083,1084,1084,1078$ and $1082 \mathrm{~cm}^{-1}$ for 1 , $2,3,4$ and 5, respectively. The thio ethers (C-S-C) vibrations were at $664,617,616,611$ and $614 \mathrm{~cm}^{-1}$ for $1,2,3,4$ and 5, respectively. Aromatic $\mathrm{C}-\mathrm{H}$ peaks occurred between 3015 and $3075 \mathrm{~cm}^{-1}$ for all of the complexes. In ${ }^{1} \mathrm{H}$-NMR spectrum of 1 to
5 , the aromatic and aliphatic protons appear at 7.12-8.60 and 2.40-3.42 ppm, respectively. In the mass spectra, the molecular ion peaks were $(\mathrm{m} / \mathrm{z})$ observed at, 2859.05 for 2, 2818.36 for 3 and 2852.65 for 4 as $\left[\mathrm{M}^{+}, 2909.40\right.$ for 5 as $\left[\mathrm{M}-\mathrm{Cl}^{+} \mathrm{H}\right]^{+}$ and for $1721 \mathrm{as}\left[\mathrm{M}^{+} \mathrm{Na}\right]+$, are in accordance with the expected values (Figure 1, using complexes 2 (a) and 3 (b) as examples).

\section{Ground State Electronic Absorption Spectra}

The absorption behaviors of the new compounds (2 to 5 ) exhibited typical spectrum of phthalocyanines, which includes two distinct bands and less intensive absorption band is about $600 \mathrm{~nm}$, one of them is in the visible region at $600-700 \mathrm{~nm}$ ( $Q$ band) and the other one is in the UV region at about $200-400 \mathrm{~nm}$ ( $\mathrm{B}$ band). These spectrum results are at 692, 690, 675 and $713 \mathrm{~nm}$ of 2, 3, 4 and 5, respectively. In the most of phthalocyanines, the $Q$ band shifts to longer wavelengths with enlargement of $\pi$ conjugated system. However, aliphatic fluorine groups in the complexes are not conjugated with the phthalocyanine $\mathrm{p}$ system [19]. That's why, these phthalocyanines showed less red shifting. The $Q$ band of the zinc phthalocyanine (2) was red-shifted when compared to the other studied metallo phthalocyanine complexes ( 3 and 4 , except for 5) in THF due to the central metal effect. Aggregation desire of phthalocyanine compounds is owing to the interactions between 


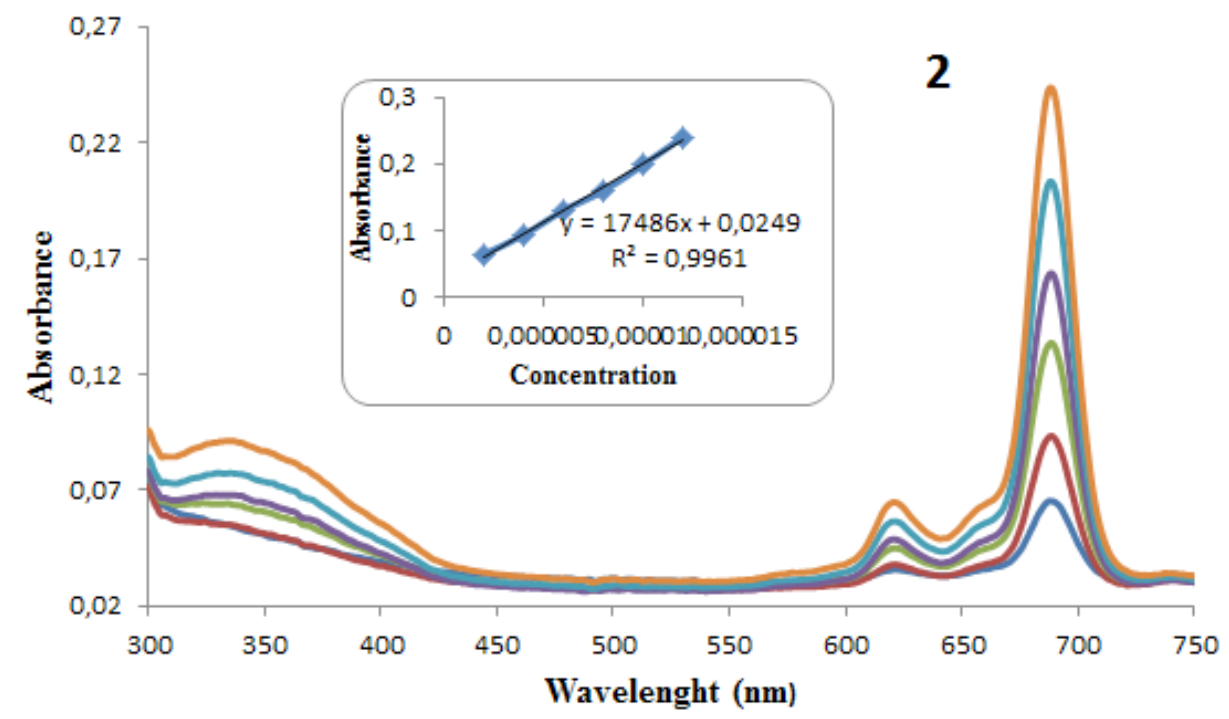

Figure 2. Absorption spectra of the complex 2 in THF at different concentrations: $2 \times 10^{-6}, 4 \times 10^{-6}, 6 \times 10^{-6}, 8 \times 10^{-6}, 10 \times 10^{-6}$,

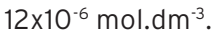

their 18 p-electron systems often cause weak solubility or insolubility in numerous solvents. The non-peripheral tetra-substituted phthalocyanines were exhibited red-shifted $Q$ bands when compared to the corresponding peripheral tetra and octa-substituted counterparts $[12,15]$. The aggregation reduces the excited state lifetimes and the photosensitizing efficiency [14]. In this study, the spectras showed monomeric behavior evidenced by single and narrow $Q$ bands, so we have achieved appropriate phthalocyanines for PDT in terms of aggregation. We also examined aggregation behavior of the fluorine group substituted phthalocyanines in the concentrations ranging from $2.0 \times 10^{-6}$ to $1.2 \times 10^{-5} \mathrm{~mol} \mathrm{dm}^{-3}$ in THF and Lambert-Beer law was obeyed as given an example for the complex 2 in THF in Figure 2. While the concentration was increasing, the intensity of absorption of the $Q$ band also increased and there were no new bands (blue shifted) observed at about $640 \mathrm{~nm}$ because of the aggregated species.

\section{Fluorescence Spectra and Quantum Yields}

Fluorescence properties were investigated in the same solvent (THF) because of solvent parameters such as polarity, viscosity, refractive index and the presence of heavy atoms in the solvent molecule, are widely known to influence the yield of fluorescence [20]. The result of absorption, fluorescence excitation and emission spectra of the complex 3 in THF are shown in
Figure 3 and are listed with Stokes shifts in Table 1. The fluorescence spectras were mirror images of the excitation spectras [21]. When we compare the $\Phi_{F}$ values consisted of the metal effect, the highest $F$ value (0.24) is for $\mathrm{ZnPc}(2)$. The value is also higher than typical metallophthalocyanines complexes [22] and unsubstituted $\mathrm{ZnPc}\left(\Phi_{\mathrm{F}}=0.17\right)$ [23]. The higher values ( 2 and 3 ) can also be explained by the non-aggregation properties and metal effect in the Pc core [24-26]. The cobalt phthalocyanine (4) showed the lowest fluorescence value (0.01) due to paramagnetic nature of the metal [27]. Non-peripherally position of the substituent improved the fluorescence quantum yields of the complexes (2 and 3 ).

\section{Photochemical Measurements}

\section{Singlet Oxygen Quantum Yields}

Singlet oxygen quantum yields of the phthalocyanines were calculated in THF to investigate the effect of metal (Table 2) and Figure 4 shows spectral changes of complex 2 in the presence of DPBF. In every metallophthalocyanine, the complex was occurred higher quantum yield than unsubstituted $\mathrm{ZnPc}$ because of the bulky fluorine group substituents. The disappearance of DPBF absorbance at $417 \mathrm{~nm}$ was monitored using UV-Vis spectroscopy. There were no changes in the $Q$ band intensities during singlet oxygen studies, confirming that complexes are not degraded in 


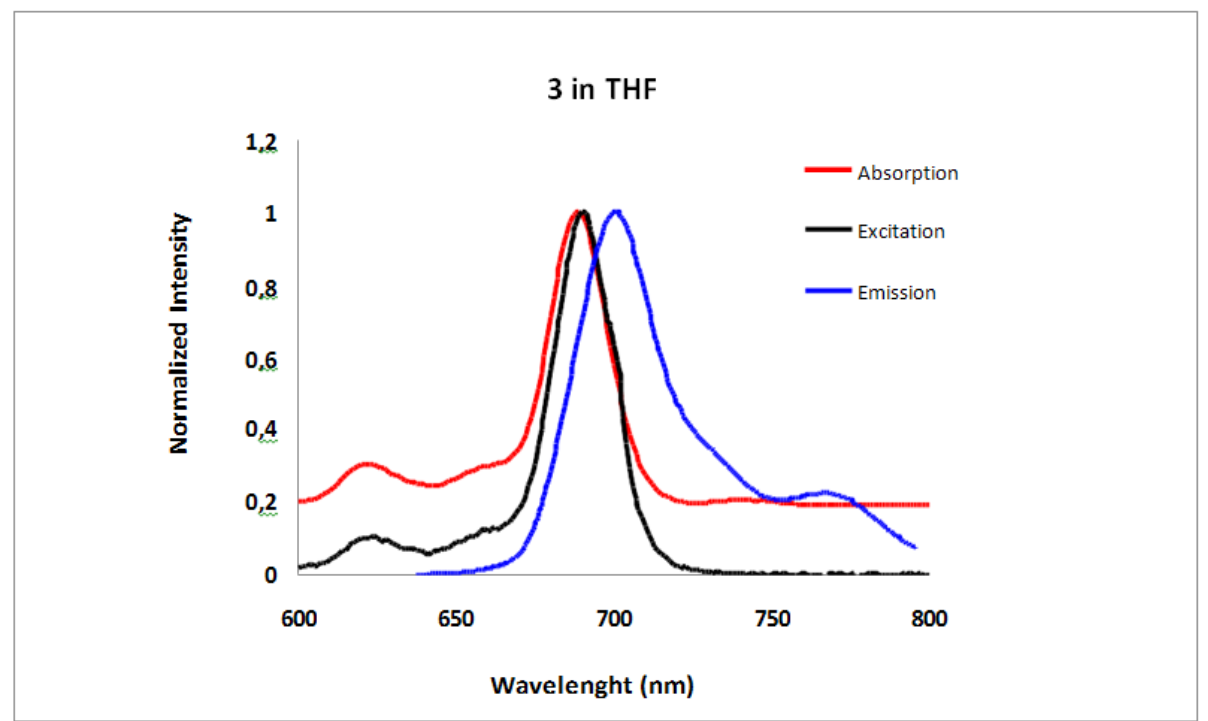

Figure 3. Absorption (690 nm), excitation $(690 \mathrm{~nm})$ and emission $(701 \mathrm{~nm})$ spectra of the complex 3 in THF. (For 3 excitation wavelength $=625 \mathrm{~nm}$ for emission and $671 \mathrm{~nm}$ for excitation in THF).

Table 1. Spectral parameters of the complexes in THF.

\begin{tabular}{cccccc}
\hline Complex & $\begin{array}{c}Q \text { band } \\
\lambda_{\max }(\mathrm{nm})\end{array}$ & $(\log \lambda)$ & $\begin{array}{c}\text { Excitation } \\
\lambda_{\mathrm{Ex}}(\mathrm{nm})\end{array}$ & $\begin{array}{c}\text { Emission } \\
\lambda_{\mathrm{Em}}(\mathrm{nm})\end{array}$ & $\begin{array}{c}\text { Stokes shift } \\
\Delta_{\text {Stokes }} \\
(\mathrm{nm})\end{array}$ \\
\hline 2 & 692 & 4.24 & 691 & 701 & 10 \\
\hline 3 & 690 & 3.92 & 690 & 701 & 11 \\
\hline 4 & 675 & 3.63 & 697 & 699 & 2 \\
\hline 5 & 713 & 3.58 & 715 & 729 & 14 \\
\hline
\end{tabular}

these studies [21-26]. As shown in Table 2, the highest quantum yield $\Delta(0.48)$ is for 2 , may be due to its absorption of light at longer wavelength than other metallophthalocyanine [27] and then it is followed by MgPc (0.30). These values of $\Delta(0.06$ to 0.48 ) for substituted metallophthalocyanines are lower than respective unsubstituted $\mathrm{ZnPc}$ $\left(\Phi_{\Delta}=0.53\right)$ [14] because of the substitutents carrying long chain fluorine atoms and metal atom effect [28]. The value of CoPc (0.06) is the lowest result [29]. This can be explained by paramagnetic nature of the metal,again. When compare to octa substituted derivatives [12], non-peripherally position of long alky chain bearing fluorine atoms groups on Pc increased singlet oxgen generation and quantum yields for zinc (2) and magnesium (3) complexes. The non-peripherally substituted phthalocyanines (2 and 3) also showed higher $\Phi_{\Delta}$ values than peripherally tetra and octa-substituted counterparts $[12,15]$. This result can be explained by the effect of the substituent position because the energy gap $\left(\Delta_{E}\right)$ between the highest occupied molecular orbital (HOMO) and lowest unoccupied molecular orbital (LUMO) is reduced due to the addition of substituents at the non- peripheral positions on the phthalocyanine framework.

\section{Photodegradation Quantum Yields}

Photodegradation quantum yield $(\mathrm{d})$ is a measure of the stability of a molecule under photo irradiation. This process was performed in THF by seeing the decrease in the intensity of the $Q$ band maxima of the complexes under irradiation with increasing time and the quantum yields $[30,15]$. Quantum yields were given Table 2 and Figure 5 for the complex 5. The new complexes arequite resistant to photochemical degradation as seen in our experiments. When we compare the photodegradation quantum yields for different metals, the lowest stability is observed for InPc (0.069) and then it is followed by $\mathrm{ZnPc}(0,010)$, $\mathrm{MgPc}(0.009)$ and $\mathrm{CoPC}(0,002)$ has the highest stability. 


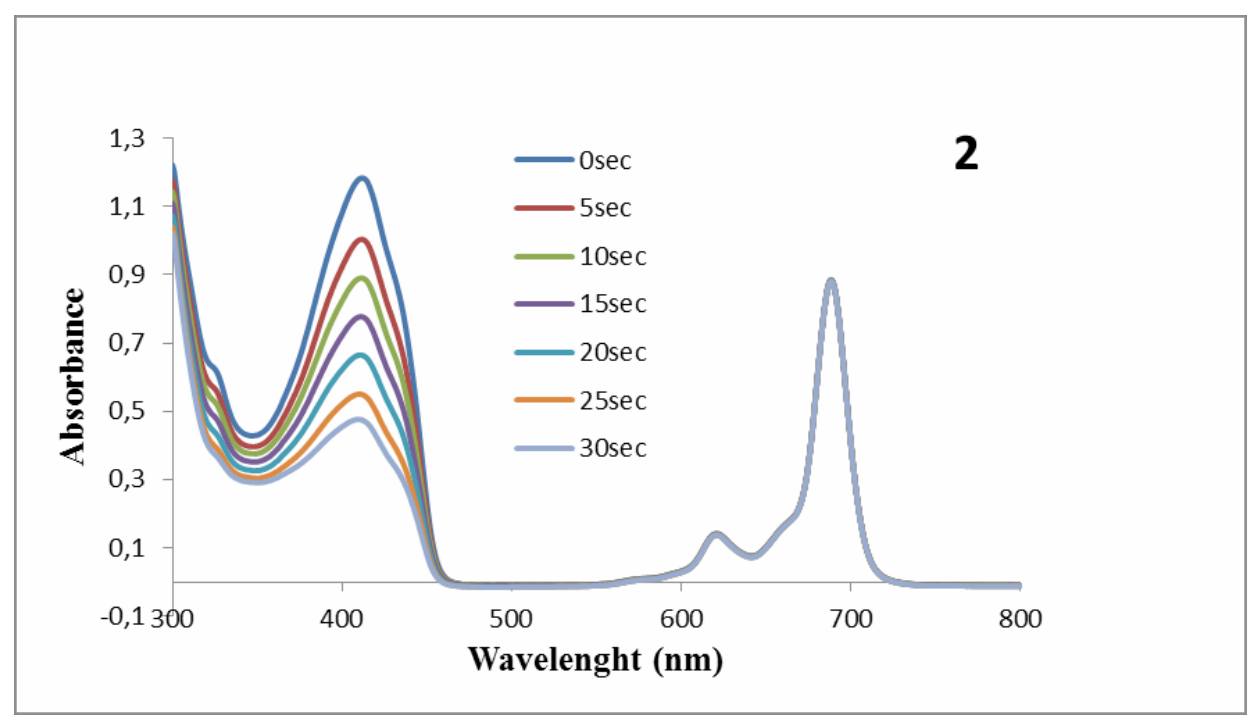

Figure 4. A typical spectrum for the determination of singlet oxygen quantum yield of the complex 2 in THF.

Table 2. Photophysical and photochemical properties of the complexes in THF.

\begin{tabular}{cccc}
\hline Complex & $\Phi_{\mathrm{F}}$ & $\Phi_{\mathrm{d}}\left(10^{-4}\right)$ & $\Phi_{\Delta}$ \\
\hline 2 & 0.24 & 0.010 & 0.48 \\
\hline 3 & 0.23 & 0.009 & 0.30 \\
\hline 4 & 0.01 & 0.002 & 0.06 \\
\hline 5 & 0.03 & 0.069 & 0.26 \\
\hline
\end{tabular}

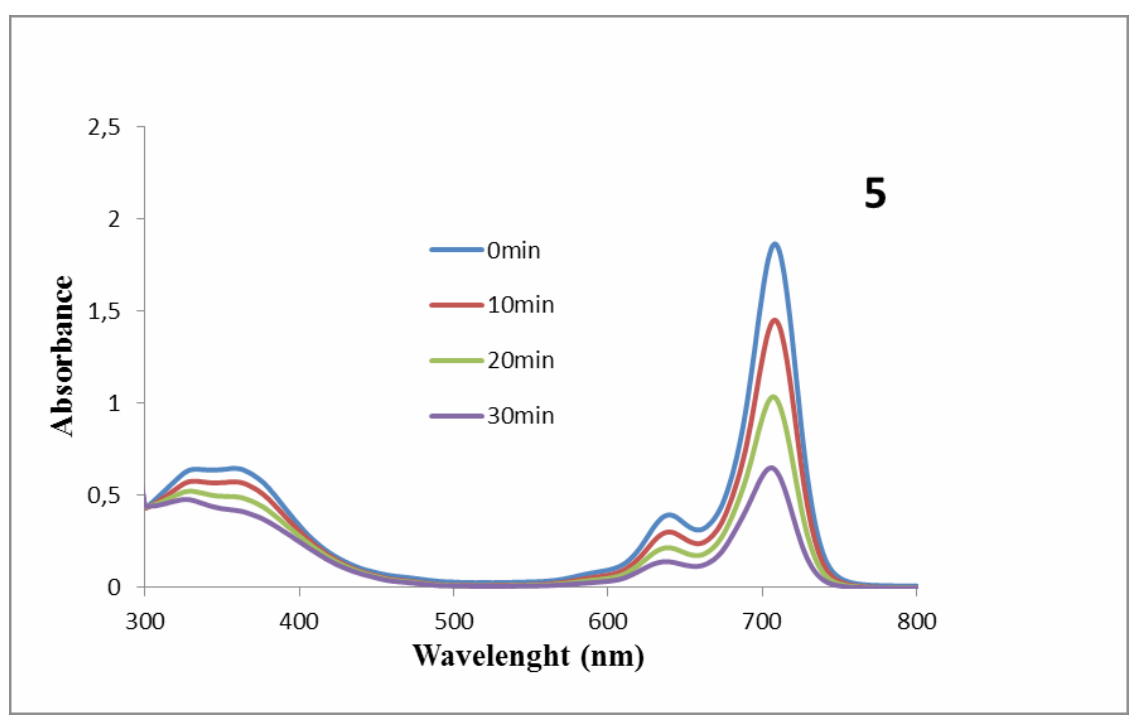

Figure 5. A typical spectrum for the determination of photodegradation of the complex 5 in THF. 


\section{CONCLUSION}

This study aimed to develop photochemical and photophysical properties of phthalocyanines with fluorine group substituted. In this way, the solubility, which is important problem in phthalocyanines, has been increased and the phthalocyanines obtained did not showed aggregation tendency from low concentration to high concentration range. Moreover, the phthalocyanines with nonperipherally positions improved photophysical properties $\left(\Phi_{\mathrm{F}} ; 0.24\right.$ for 2 and 0.23 for 3$)$ when compared to peripherally ones $\left(\Phi_{F} ; \mathrm{ZnPc}: 0.160\right.$, MgPc: 0.025). It is well known, that the properties are strongly influenced by the presence of subtitutent and nature of the central metal ion. That's why, we studied with different metals ( $\mathrm{n}$, $\mathrm{Mg}, \mathrm{Co}$ and $\mathrm{In}$ ). While complex 4 has the lowest singlet oxygen quantum yield (0.06), $2(0.48), 3$ $(0.30)$ and $5(0.26)$ have higher singlet oxygen quantum yield values in THF and the highest efficent is for 2 (0.48). Because, diamagnetic ions, like $\mathrm{Zn}^{+2}, \mathrm{In}^{3+}$ give phthalocyanine compounds both high singlet oxygen generation and triplet yields. These results demostrate an exhibit of the new metallophthalocyanines as photosensitizers in photocatalytic applications such PDT.

\section{ACKNOWLEDGEMENTS}

This study was supported by Yıldız Technical University (Project No: 2014-01-02- DOP 3 )

\section{References}

1. P.A. Stuzhin, O.G. Khelevina, S.Angeoni, B.D. Berezin in: C.C. Leznoff, A.B.P. Lever, Properties and Applications, 1996, VCH: vol. 4.

2. P.A. Stuzhin, Azaporphyrins and phthalocyanines as multicentre conjugated ampholites, J. Porphyr Phthalocya, 3 (1999) 500.

3. E. Kırbaç, G. Yaşa Atmaca, A. Erdoğmuş, Novel highly soluble fluoro, chloro, bromo-phenoxyphenoxy substituted zinc phthalocyanines; synthesis, characterization and photophysicochemical properties, J. Organomet. Chem., 752 (2014) 115

4. T.F. Dougherty, Photodynamic therapy (PDT) of malignant tumors, Crit. Crit. Rev. Oncol. Hematol., 2 (1984) 83.

5. T. Nyokong, Effects of substituents on the photochemical and photophysical properties of main group metal phthalocyanines, Coordin. Chem. Rev., 251 (2007) 1707-1722.
6. N.B. Mckeown, Phthalocyanine materials: synthesis, structure and function; Cambridge University, 1998.

7. D. Arıcan, M. Arıcl, A.L. Uğur, Erdoğmuş, A. Koca, Effects of peripheral and nonperipheral substitution to the spectroscopic, electrochemical and spectroelectrochemical properties of metallophthalocyanines, Electrochim. Acta, 106 (2013) 541.

8. P. Zimcik, M. Miletin, J. Ponec, M. Kostka, Z. Fiedler, Synthesis and studies on photodynamic activity of new water-soluble azaphthalocyanines, J. Photochem. Photobiol. A Chem., 155 (2003) 127.

9. A. Erdoğmuş, A. Koca, U. Avciata, A. Gül, Synthesis, Characterization and Electrochemistry of New Soluble Porphyrazine Complexes Bearing Oktakis 3Methylbutylthio Substituents, Z. Anorg. Allg. Chem., 634 (2008) 2649.

10. a) M. Arıcl, D. Arıcan, A.L. Uğur, A. Erdoğmuş, A. Koca, Electrochemical and spectroelectrochemical properties of novel lutetium(III) mono- and bisphthalocyanines, Electrochim. Acta, 113 (2013) 668. b) C. Bozoğlu, M. Arıcı, A.L. Uğur, A. Erdoğmuş, A. Koca, Electrochemical and Spectroelectrochemical Properties of methylendioxy-phenoxy-substituted Novel Lu(III) Mono- and Bis- phthalocyanines, Synth. Met., 190 (2014) 56.

11. T. Furuto, S.K. Lee, Y. Amao, K. Asai, I. Okura, Oxygen sensing system using triplet-triplet reflectance of zinc porphyrin immobilized in polymer membrane studies by laser flash photolysis, J. Photochem. Photobiol. A Chem., 132 (2000) 81.

12. A. Erdoğmuş, M. Arıcı, Novel soluble octa-substituted phthalocyanines bearing chloro and long alkyl chain containing fluorine: Synthesis, characterization and photophysical and photochemical properties, J. Fluorin. Chem., 166 (2014) 127.

13. G. Yaşa, A. Erdoğmuş, A.L. Uğur, M.K. Şener, U. Avcıata, T. Nyokong, Photophysical and photochemical properties of novel phthalocyanines bearing nonperipherally mercaptoquinoline moiety, J. Porphyr. Phthalocya., 16 (2012) 845.

14. A. Ogunsipe, D. Maree, T. Nyokong, Solvent effects on the photochemical and fluorescence properties of zinc phthalocyanine derivatives, J. Mol. Struct., 650 (2003) 131.

15. A. Erdoğmuş, T. Nyokong, Novel, soluble, FluXoro functional substituted zinc phthalocyanines; synthesis, characterization and photophysicochemical properties, Dyes Pigments, 86 (2010) 174.

16. M. Idowu, T. Nyokong, Photophysicochemical and fluorescence quenching studies of tetra- and octa-carboxy substituted silicon and germanium phthalocyanines, J. Photochem. Photobiol. A Chem., 204 (2009) 63.

17. A. Ogunsipe, T. Nyokong,Photophysical and photochemical studies of sulphonated non-transition metal phthalocyanines in aqueous and non-aqueous media, J. Photochem. Photobiol. A Chem. 173 (2005) 211.

18. B. Sezer, M.K. Sener, A. Koca, A. Erdoğmuş, U. Avciata, Synthesis, electrochemistry, spectroelectrochemistry and electrocolorimetry of phthalocyanine-anthraquinone dyes, Synth. Met., 160 (2010) 2155. 
19. A.C. Beveridge, B.A. Bench, S.M. Gorun, G.J. Diebold Evaluation of photodynamic therapy agents through transient grating measurements, J. Phys. Chem. A 107 (2003) 5138.

20. C. Öztürk, A. Erdoğmuş, M. Durmuş, A.L. Uğur, F.A. Kılıçarslan, i. Erden, Highly soluble 3,4-(dimetoxyphenylthio)substituted phthalocyanines: synthesis, photophysical and photochemical studies, Spectrochim. Acta A, 86 (2012) 423.

21. A. Erdoğmuş, S. Moeno, C. Litwinski, T. Nyokong, Photophysical properties of newly synthesized fluorinated zinc phthalocyanines in the presence of CdTe quantum dots and the accompanying energy transfer processes, J. Photochem. Photobiol. A Chem. 210 (2010) 200.

22. A. Erdoğmuş, M. Durmuş, A.L. Uğur, O. Avciata, U. Avciata, T. Nyokong, Synthesis, photophysic, photochemistry and fluorescence quenching studies on highly soluble substituted oxotitanium (IV) phthalocyanine complexes, Synth. Met., 160 (2010) 1868.

23. A. Lütfi Uğur, A. Erdoğmuş, A. Koca, U. Avcıata, Synthesis, spectroscopic and electrochemical and Spectroelectrochemical properties of metal free, manganese and cobalt phthalocyanines bearing peripherally octakis-4-(Thiophen-3yl)-phenoxy, Polyhedron, 29 (2010) 3310.

24. A. Erdoğmuş, A. Koca, A.L. Uğur, I. Erden, Synthesis, electrochemical and spectroelectrochemical properties of highly soluble tetra substituted phthalocyanines with [4-(Thiophen-3yl)-phenoxy], Synth. Met., 161 (2011) 1319.
25. A. Erdoğmuş, A. Ogunsipe, T. Nyokong, Synthesis, photophysics and photochemistry of novel tetra(quinoxalinyl)phthalocyaninatobzinc(II) complexes, J. Photochem. Photobiol. A: Chem., 205 (2009) 12.

26. A. Erdoğmuş, T. Nyokong, Synthesis of zinc phthalocyanine derivatives with improved photophysicochemical properties in aqueous media, J. Mol. Struct., 977 (2010) 26.

27. M. Kandaz, M.N Yarasır, A. Koca, Ö. Bekaroglu, Synthesis, characterization and electrochemistry of novel differently octasubstituted phthalocyanines, Polyhedron, 21 (2002) 255.

28. W. Spiller, H. Kliesch, D. Worhle, S. Hackbarth, B. Röder, G. Schnurpfeil, Singlet oxygen and solvents and micellar solutions J. Porphyr. Phthalocya., 2 (1998) 145

29. Y. Zorlu, F. Dumoulin, D. Bouchu, V. Ahsen, D. Lafont, Monoglycoconjugated water-soluble phthalocyanines. Design and synthesis of potential selectively targeting PDT photosensitisers, Tetrahedron Lett., 51 (2010) 6615

30. M. Özer, A. Altindal, M. Mustafa, Synthesis, characterization and some properties of novel bis(pentafluorophenyl)methoxyl substituted metal free and metallophthalocyanines, Polyhedron, 25 (2006) 3593. 